УДК 577.12:611.018.51

(C) 2013

Гутий Б. В., кандидат ветеринарних наук

Львівський національний університет ветеринарної медицини та біотехнологій імені С. 3. Гжицького

\title{
ВПЛИВ ХЛОРИДУ КАДМІЮ НА СТАН АНТИОКСИДАНТНОЇ СИСТЕМИ У ПЕЧІНЦІ ЩУРІВ
}

\section{Рецензент - доктор ветеринарних наук, професор В. І. Завірюха}

\begin{abstract}
Розкрито особливості антиоксидантної системи організму щурів за хронічного кадмієвого токсикозу. Встановлено, щзо хлорид кадмію у токсичній дозі сприяє зниженню активності ферментної й неферментної системи антиоксидантного захисту, на щзо вказує зниження ферментів глутатіонпероксидази, глутатіонредуктази, супероксиддисмутази, каталази та відновленого глутатіону у печінці щурів. Результати досліджень вказують на те, щзо хронічний кадмієвий токсикоз призводить до посиленої активаціï процесів ліпопероксидації.
\end{abstract}

Ключові слова: токсикологія, кадмій, антиоксидантна система, ферменти, печінка, щури.

Постановка проблеми. Нині існує значна кількість наукових повідомлень про надзвичайно важливу роль перекисного окиснення ліпідів (ПОЛ) у розвитку багатьох токсикозів $[1,2]$. Необхідною умовою функціонування клітини $\epsilon$ підтримка нормального рівня процесів ПОЛ, швидкість і регуляція яких контролюється багатокомпонентною антиоксидантною системою $(\mathrm{AOC})$, що забезпечує зв'язування й модифікацію вільних радикалів, попередження утворення та руйнування перекисів. Слід відзначити, що дана система складається 3 ферментної та неферментної ланок. Особливу роль у функціонуванні природної АОС відіграють ферменти - антиоксиданти, до числа яких відносяться супероксиддисмутаза, каталаза, глутатіонредуктаза, глутатіонпероксидаза [3].

Аналіз останніх досліджень і публікацій, у яких започатковано розв'язання проблеми. У попередніх наших дослідженнях встановлено, що за кадмієвої інтоксикації посилюються процеси перекисного окиснення ліпідів, що, з одного боку, зумовлено активністю радикалоутворення, а 3 іншого, - буферною ємністю системи антиоксидантного захисту, яка визначає адаптаційну спроможність клітини та організму в цілому. 3 цього приводу вважаємо доцільним, 3 огляду на досвід дослідників, узагальнити й охарактеризувати стан антиоксидантної системи організму тварин за хронічного кадмієвого токсикозу.
Мета і завдання досліджень. Метою наших досліджень було встановлення впливу хлориду кадмію у дозі 4,4 мг/кг на активність системи антиоксидантного захисту організму щурів для подальшої розробки антидоту для лікування тварин за означеної вище інтоксикації. Завданнями було розкрити патогенез токсичної дії кадмію на організм щурів; розробити антидот за кадмієвої інтоксикації.

Матеріали і методи досліджень. Досліди проводились на щурах-самцях лінії Вістар, масою 200-220 г, 3 яких було сформовано 2 групи тварин: 1-ша контрольна група (вводили питну воду через металевий зонд в об'ємі, який еквівалентний об'єму водного розчину солей $\mathrm{Cd}^{2+}$ ); 2-га дослідна група - вводили $0,029 \%$ водний розчин хлориду кадмію в дозі 4,4 мг/кг.

Результати досліджень. Важливою у системі антиоксидантного захисту є глутатіонзалежна ланка цієї системи, що включає ферменти - глутатіонпероксидазу та глутатіонредуктазу, а також неферментний показник - відновлений глутатіон. Як видно 3 даних таблиці, під впливом хлориду кадмію активність глутатіонпероксидази печінки знижувалася протягом усього досліду. Найнижчу активність ферменту, який досліджувався, встановлено на 8-у та 16-у доби досліду, де, відносно величин контрольної групи тварин, показники були вищі на 39 і 45 \%. На 24-у добу досліду встановлено підвищення активності ГП, де відносно попередньої доби досліду вона зросла на $42 \%$. На 30-у добу досліду активність ГП печінки становила $21,41 \pm 0,45$ ммоль/(хв'кг).

Глутатіонредуктазна активність печінки тварин, отруєних хлоридом кадмію, також зазнавала певних змін. Так, даний показник антиоксидантного захисту вірогідно знижувався на першу добу на $19 \%$; на восьму добу досліду - на $27 \%$, на 16-у і 24-у доби дослідження - на 32 і $17 \%$ відносно групи інтактних тварин.

Майже аналогічна динаміка виявлена в процесі дослідження вмісту відновленого глутатіону у тканині печінки. За дії на організм щурів хлориду кадмію вміст G-SH в печінці знижувався на 9,9\% 
ВЕТЕРИНАРНА МЕДИЦИНА

Стан антиоксидантної системи щурів за хронічного кадмієвого токсикозу $(M \pm m, n=12)$

\begin{tabular}{|c|c|c|c|c|c|c|}
\hline \multirow{2}{*}{ Показник } & \multicolumn{5}{|c|}{ Група тварин } \\
\cline { 2 - 6 } & \multirow{2}{*}{ контрольна } & \multicolumn{5}{|c|}{ дослідна; доба експерименту } \\
\cline { 2 - 6 } & & $1-ш а$ & $8-$-а & $16-$-та & $24-$-та & 30 -та \\
\hline ГП печінки, & $23,29 \pm$ & $17,29 \pm$ & $14,19 \pm$ & $12,90 \pm$ & $18,24 \pm$ & $21,41 \pm$ \\
ммоль/(хв*кг) & 0,21 & $0,38 * *$ & $0,35 * *$ & $0,36 * *$ & $0,46 * *$ & $0,45 *$ \\
\hline ГР печінки, & $11,25 \pm$ & $9,11 \pm$ & $8,20 \pm$ & $7,68 \pm$ & $9,38 \pm$ & $10,14 \pm$ \\
ммоль/(хв*кг) & 0,25 & $0,22 * *$ & $0,24 * *$ & $0,19 * *$ & $0,25 * *$ & $0,32 *$ \\
\hline G-SН печінки, & $3,45 \pm$ & $3,11 \pm$ & $2,90 \pm$ & $2,31 \pm$ & $2,43 \pm$ & $2,78 \pm$ \\
ммоль/кг & 0,07 & $0,07 *$ & $0,05 * *$ & $0,06 * *$ & $0,05 * *$ & $0,08 * *$ \\
\hline СОД печінки, & $0,615 \pm$ & $0,521 \pm$ & $0,497 \pm$ & $0,450 \pm$ & $0,560 \pm$ & $0,582 \pm$ \\
ум. од./мГ & 0,014 & $0,013 *$ & $0,014 * *$ & $0,014 * *$ & $0,014 * *$ & $0,015 *$ \\
\hline Каталаза печінки, & $0,125 \pm$ & $0,119 \pm$ & $0,104 \pm$ & $0,092 \pm$ & $0,098 \pm$ & $0,110 \pm$ \\
мкмоль/хв мг білка & 0,005 & 0,005 & $0,004 *$ & $0,005 * *$ & $0,003 * *$ & $0,005 *$ \\
\hline
\end{tabular}

на першу добу дослідження порівняно з групою контрольної групи тварин, на $16 \%$ - на восьму добу досліджень. На 16-у добу досліду вміст відновленого глутатіону у печінці дослідної групи тварин був найнижчим, i, відповідно, становив 2,31 $\pm 0,06$ ммоль/кг; на 24-у добу досліду вміст відновленого глутатіону дещо зріс і відносно величин контрольної групи тварин знизився на $30 \%$. На 30-у добу досліду вміст відновленого глутатіону доходив до величин восьмої доби досліду $(2,78 \pm 0,08$ ммоль/кг).

Отже, напрям змін глутатіонової ланки антиоксидантної системи за хронічного отруєння тварин хлоридом кадмію був протилежний до напряму змін показників, що відображають перекисне окиснення ліпідів.

Активність СОД у печінці за дії на організм хлориду кадмію знижувалася, відносно контрольної групи тварин; на першу добу досліду на $15 \%$, на 8-у добу досліду - на $19 \%$. До того ж найнижча активність ферменту виявлена на 16-у добу досліду (на 27 \%), порівняно з групою інтактних щурів. У наступні доби дослідження активність супероксиддисмутази знижувалася на 9 \% (24-а доба) і 5 \% (30-а доба) порівняно з аналогічним показником у групі контрольних тварин. Зниження активності СОД, ймовірно, $є$ ознакою пригнічення синтезу ферменту під впливом отруєння хлоридом кадмію. Відомо, що активність супеоксиддисмутази в організмі тварин

\section{БІБЛІОГРАФІЯ}

1. Абрагамович О. О. Процеси ліпідної пероксидації при хронічних ураженнях печінки / О. О. Абрагамович, О. І. Грабовська, О. І. Терлецька [та ін.] // Медична хімія. -2000 . - Т. 2, № 1. - С. 5-8.

2. Боріков $О$. Ю. вплив хлориду кадмію та пероксиду водню на процеси пероксидного окислення i фракційний склад ліпідів у гепатоцитах щурів / тісно пов'язана з активністю каталази, яка захищає організм від високотоксичних кисневих радикалів. Дані ферменти повинні знаходитися у балансі один до одного, поскільки занадто різке підвищення активності СОД (без відповідної активації каталази) само по собі $є$ цитотоксичним. Зміни активності каталази у щурів у випадку розвитку кадмієвого токсикозу наведені у таблиці. Активність каталази у печінці як контрольної, так і дослідної груп на початку досліду знаходилася в межах величин фізіологічної норми. Після задавання хлориду кадмію каталазна активність печінки, починаючи 3 першої доби дослідження, почала знижуватися, де, відповідно, 3 початком досліду вона знизилася на $4,8 \%$.

\section{Висновки:}

1. Наведені результати досліджень вказують на те, що хронічний кадмієвий токсикоз призводить до посиленої активації процесів ліпопероксидації та порушення рівноваги між активністю антиоксидантної системи й інтенсивністю перекисного окиснення ліпідів.

2. Проведені дослідження дали можливість глибше розкрити патогенез токсичної дії кадмію на організм щурів і використати ці дані в розробці антидоту за кадмієвої інтоксикації.

Подальші дослідження будуть проводитися 3 метою розробки антидотного препарату для лікування тварин, хворих на хронічний кадмієвий токсикоз.

Боріков О. Ю., Каліман П. А. // Український біохімічний журнал. - 2004. - Т. 76, № 2. - С. 107-111. 3. Кориун M. М. Експериментальне вивчення механізмів комбінованої дії малих доз пестицидів, нітратів, солей свинцю та кадмію / Коршун М. М., Колесова Н. А., Веремій М. І. [та ін.] // Современные проблемы токсикологии. - 2001. - № 3. - С. 46-50. 